\title{
O JOGO DE XADREZ: \\ IMAGEM, PODER E IGREJA \\ (FIM DO SÉCULO X - INÍCIO DO SÉCULO XII)*
}

Philippe Cordez

Kunsthistorisches Institut in Florenz

Max-Planck-Institut

\section{Resumo}

$\mathrm{O}$ jogo de xadrez, oriental em sua origem, foi adaptado a partir do século $\mathrm{X}$ às realidades sociais e militares do Ocidente. Os códigos de exercício do poder feudal eram simbolizados pela manipulação de suas peças. A análise de quatro usos não lúdicos das peças do xadrez, nas igrejas de Münster, Aix-la-Chapelle, Saint-Denis e Reims, enfatiza a contribuição do jogo para a definição simbólica do Império germânico e do Reino de França.

\section{Pallavras-chave}

Xadrez $\bullet$ objetos $\bullet$ igrejas.

\section{Contato:}

Kunsthistorisches Institut in Florenz, Max-Planck-Institut

Via Giuseppe Giusti 44

50121 - Firenze - Italia

E-mail:cordez@khi.fi.it

* Tradução de Maria Cristina Correia Leandro Pereira. Todas as imagens mencionadas neste artigo estão reproduzidas no Caderno de imagens. 


\title{
THE CHESSGAME: \\ IMAGE, POWER AND THE CHURCH \\ (LATE TENTH-EARLY TWELFTH CENTURY)
}

Philippe Cordez

Kunsthistorisches Institut in Florenz

Max-Planck-Institut

\begin{abstract}
Originated in the East, the chessgame was adapted to the Western social and military realities since the tenth century. The codes for the exercise of feudal power were symbolized through the manipulation of its pieces. The analysis of four uses of chess pieces outside the realm of the chessgame, in the churches of Münster, Aachen, SaintDenis and Reims, underlines the contribution of chess for the definition of the German Empire and of the French Kingdom.
\end{abstract}

\section{Keywords}

Chess $\bullet$ objects $\bullet$ churches.

\section{Contato:}

Kunsthistorisches Institut in Florenz, Max-Planck-Institut

Via Giuseppe Giusti 44

50121 - Firenze - Italia

E-mail: cordez@khi.fi.it

Translation by Maria Cristina Correia Leandro Pereira. 
Oriental em sua origem, isto é, indiano e difundido com a expansão do Islã, o jogo de xadrez foi introduzido e praticado a partir do século X no Ocidente, onde suas peças sofreram uma adaptação às realidades sociais locais. ${ }^{1}$ De um lado e de outro do antigo "shah" (daí scachus e depois xadrez, em português) que se tornou rei, e do vizir metamorfoseado em rainha, acumulavam-se, nas sessenta e quatro casas do tabuleiro, comiti, equi, marchi e pedi: os condes substituindo os elefantes; os cavaleiros; os marqueses nas margens, no lugar das carruagens; e uma tropa de soldados a pé na primeira linha. O conjunto constituía dois "povos" (populi) que se afrontavam seguindo regras estabelecidas, como testemunha o Versus de scachis, poema latino copiado na metade do século X no mosteiro beneditino de Einsiedeln, na Suíça, que nomeia as peças e descreve seu movimento, louvando o jogo como uma recreação mental, sem risco físico e nem falso juramento. ${ }^{2}$ Essas peças correspondiam aos atores do sistema feudal que organizava, por então, a sociedade ocidental de acordo com relações de dominação e de obrigações recíprocas ligando senhores e seus vassalos, homens livres que juravam fidelidade e assistência militar, recebendo terras em "feudo" (feodum) para prover suas despesas. ${ }^{3}$ Aqueles que manipulavam as peças do xadrez, geralmente figuradas em seus traços esquemáticos, da forma como haviam sido tomadas à cultura islâmica, podiam se imaginar em ação em tais configurações sociais e militares, representando, casa a casa, o desenrolar de uma conflito antes de fazer desaparecer os protagonistas um a um, até o desfecho fatal da partida. ${ }^{4}$

${ }^{1}$ Esse artigo pôde se beneficiar das discussões quando de apresentações em Münster, São Paulo e Rio de Janeiro. Agradeço, em particular, a Torsten Hiltmann, Thomas Lentes, Eduardo Henrik Aubert, Maria Cristina C. L. Pereira, Andréia Cristina Lopes Frazão da Silva e Leila Rodrigues da Silva.

2 Versus de scachis. SILAGI, Gabriel, BISCHOFF, Bernhard (ed.). Die lateinischen Dichter des deutschen Mittelalters. Die Ottonenzeit. 3 t. München: MGH, 1937-1979 (MGH, Poetae latini medii aevi, 5,3), t. 3, p. 652-655. Ver GAMER, Helena M. The earliest evidence of chess in Western literature: the Einsiedeln verses. Speculum. Cambridge, Massachusets: Cambridge University Press, 29/4, 1954, p. 734-750.

3 Ver, para orientação, GUERREAU, Alain. Féodalité. In: LE GOFF, Jacques, SCHMITT, JeanClaude (dir.). Dictionnaire raisonné de l'Occident médiéval. Paris: Fayard, 1999, p. 387-406.

4 Ao longo das evoluções sociais da Idade Média, e de forma diferente segundo as regiões, peças não militares foram integradas ao jogo: os condes se transformaram em bispos, juízes ou loucos, o marquês se tornou rocha ou torre, enquanto que dos soldados a pé se fizeram camponeses. Diferentes maneiras de jogar coexistiram por longo tempo, implicando, por vezes, a utilização de dados, privilegiando os combates de proximidade e rápidos, como na guerra feudal. Foi apenas no final da Idade Média que a prática do jogo, progressivamente uniformizada, tornou-se uma atividade intelectual. Sobre a história do xadrez: MURRAY, Harold James Ruthven. A history of chess. Oxford: Clarendon Press, 1913; última reimpr, 2007; MEHL, Jean-Michel. Les jeux au royaume de France du XIII au début du xVIe siècle. Paris: Fayard, 1990, esp. p. 115-134; STROUHAL, Ernst (dir.). Vom Wesir zur Dame. Kulturelle Regeln, ihr Zwang und ihre Brü- 
O jogo de xadrez, jogo de imagens, tinha, portanto, relação com o "imaginário do feudalismo". A expressão foi introduzida pelo historiador Georges Duby, familiarizado com as imagens medievais e a arte do século XX, para sublinhar como uma ideologia pode contribuir para fixar relações sociais, ${ }^{5}$ e a ideia, de inspiração surrealista, de que o imaginário "faz parte da realidade" guiou as pesquisas de Michel Pastoureau sobre a simbologia e a sensibilidade medievais e, entre outros temas, sobre o xadrez. ${ }^{6}$ Como figuram atores do poder profano e suas interações, as peças do xadrez evocavam esse poder sem que o próprio soberano se servisse, necessariamente, de sua demonstração. ${ }^{7}$ A sociedade codificada do jogo lembrava os códigos da verdadeira vida social dos poderosos de então: os soberanos e seu círculo recorriam, de fato, a representações de pessoas, gestos e objetos que os observadores envolvidos deveriam saber interpretar, antes de empregar tal repertório em outras situações, variando-o e refinando-o para atualizar sua eficácia. Os autores de textos e os criadores de imagens também recorriam a essas convenções culturais e a essas formas simbólicas a fim de dar conta dos acontecimentos e de participar deles e, a partir desses documentos, os historiadores buscam compreender as "regras do jogo" do cenário político medieval, apreciando suas nuances e descrevendo sua evolução. ${ }^{8}$ Como o jogo

chigkeit. Über kulturelle Transformationen am Beispiel des Schachspiels. Wien: Internationales Forschungszentrum Kulturwissenschaften, 1995; MAKARIOU, Sophie. Le jeu d'échecs, une pratique de l'aristocratie entre Islam et chrétienté des IXe-XIIIe siècles. Les Cahiers de SaintMichel de Cuxa. Codalet: Association culturelle de Cuxa, 36, 2005, p. 127-140.

5 Duby se limitou à análise dos "traços escritos. Nosso material único": DUBY, Georges. Les trois ordres ou l'imaginaire du féodalisme, Paris: Gallimard, 1978, p. 20. Sobre o autor, ver: DUHAMEL-AMADO, Claudie. LOBRICHON, Guy (dir.). Georges Duby. L'écriture de l'histoire. Bruxelles: De Boeck-Wesmael, 1996; DE LA RONCIÈRE, Charles M., ATTARDMARANINCHI, Marie-Françoise. Georges Duby. L'art et l'image. Une anthologie. Marseille: Parenthèses, 2000; SEISCHAB, Steffen. Imaginer la société féodale. Georges Dubys Bild des Mittelalters. Frankfurt am Main: Peter Lang, 2005.

6 Ver PASTOUREAU, Michel. L'échiquier de Charlemagne. Un jeu pour ne pas jouer. Paris: Adam Biro, 1990; Idem. Le symbole médiéval. Comment l'imaginaire fait partie de la réalité. In: Idem. Une histoire symbolique du Moyen Âge occidental. Paris: Seuil, 2004, p. 11-25. Sobre sua familiaridade de criança com André Breton, de quem seu pai era próximo, Idem. Les couleurs de nos souvenirs. Paris: Seuil, 2010, p. 17-19. Sobre o "caso Pastoureau" que abalou o grupo surrealista em 1951, GERSHMAN, Herbert S. L'affaire Pastoureau. Yale french studies. New Haven: Yale University, 31, 1964, p. 154-158.

7 Ver SCHRAMM, Percy Ernst, et al. Herrschaftszeichen und Staatssymbolik. Beiträge zu ihrer Geschichte vom dritten bis zum sechzehnten Jahrhundert. 4 t. Stuttgart: Hiersemann, 1954-1978.

8 A metáfora do jogo é recorrente nesses estudos. Ver ALTHOFF, Gerd. Spielregeln der Politik im Mittelalter. Kommunikation in Frieden und Fehde. Darmstadt: Wissenschaftliche Buchgesellschaft, 1997; KAMP, Hermann, GARNIER, Claudia (dir.). Spielregeln der Mächtigen. Mittelalterliche Politik zwischen Gewohnheit und Konvention. Darmstadt: Wissenschaftliche Buchgesellschaft, 2010. Ver, em particular, sobre o papel das imagens, KELLER, Hagen. Ritual, 
de xadrez, imagem por excelência do jogo social, cuja complexidade ele reduzia artificialmente ao levá-lo para o domínio das representações, participava, pois, das questões sociais?

Os sítios arqueológicos dão testemunho, através de objetos comuns, em osso, madeira ou chifre, da difusão progressiva do jogo de xadrez desde o século X e sobretudo ao longo do século XI, especialmente no seio da pequena aristocracia. ${ }^{9}$ Seria necessário se perguntar de que modo a introdução e, em seguida, a moda desse jogo poderiam estar ligados, para além dos fatores externos da migração cultural, às transformações da sociedade feudal dos séculos X e XI - com a fixação territorial de uma aristocracia anteriormente bastante móvel, com a criação do castelo e, logo em seguida, com uma reorganização da exploração das terras e, por conseguinte, com uma evolução dos modos de vida e das realidades militares representadas no jogo. Quem tinha prazer e interesse em representar tais conflitos na intimidade de uma partida? Os diversos usos metafóricos, principalmente cortesãos e moralizantes, dos quais o xadrez foi objeto a partir do século XII e sobretudo do XIII, não esclarecem necessariamente esses primeiros tempos de sua história ocidental. A presente contribuição busca interrogar as relações entre o jogo de xadrez e a Igreja, que foi a instituição central do sistema social feudal, embora nenhum papel lhe houvesse sido concedido no tabuleiro. Pode-se observar, de fato, que, entre o fim do século X e o início do XII, houve doações recorrentes de materiais de xadrez a igrejas e mesmo, por vezes, tais materiais foram reempregados como objetos complexos. Isto é bem conhecido pelos historiadores do xadrez, porque foi através das igrejas, fora de qualquer função lúdica, que as peças mais luxuosas chegaram até nós. A explicação corrente para tal fato defende que esses dons teriam sido motivados apenas pela preciosidade

Symbolik und Visualisierung in der Kultur des ottonischen Reiches. Frühmittelalterliche Studien. Berlim: de Gruyter, 35, 2001, p. 23-59, e ALTHOFF, Gerd. Die Bilder der mittelalterlichen Historiographie. In: STOLLBERG-RILINGER, Barbara, WEISSBRICH, Thomas (dir.). Die Bildlichkeit symbolischer Akte. Münster: Rhema, 2010, p. 23-35, que responde notadamente a BUC, Philippe. The dangers of ritual. between early medieval texts and social scientific theory. Princeton: Princeton University Press, 2001; 2009.

9 Ver KLUGE-PINSKER, Antje. Schach und Trictrac. Zeugnisse mittelalterlicher Spielfreude aus salischer Zeit. Sigmaringen: Thorbecke, 1991; GABORIT-CHOPIN, Danielle (dir.). La France romane aux temps des premiers capétiens (987-1152). Cat. exp. Paris: Musée du Louvre/Hazan, 2005, p. 188-191. Sobre os materiais de xadrez posteriores, ver STRATFORD, Neil. The Lewis chessmen and the enigma of the hoard. Londres: British Museum Press, 1997; WICHMANN, Hans, WICHMANN, Siegfried. Schach. Ursprung und Wandlung der Spielfigur in zwölf Jahrhunderten. München: Callwey, 1960; SCHAFROTH, Colleen. The art of chess. Nova Iorque: Abrams, 2002; HOLLÄNDER, Hans, HOLLÄNDER, Barbara (dir.). Schachpartie. Durch Zeiten und Welten. Cat. exp. Hamburg, Heidelberg: Braus im Wachter-Verlag, 2005. 
dos objetos, como se eles cessassem de ser peças de xadrez ou tabuleiros uma vez adentrados no espaço eclesiástico. Ora, tudo indica que essas "conversões" eram, ao contrário, atos simbólicos elaborados com cuidado, com o objetivo de estabelecer e manifestar uma relação entre os atores do poder profano e militar e as instituições eclesiásticas. ${ }^{10}$ Eis aqui, sem dúvida, a expressão mais espetacular das implicações sociais do jogo de xadrez nos primeiros tempos de sua história ocidental. Neste artigo, iremos nos concentrar na análise de quatro objetos relacionados ao Império germânico e ao Reino de França, respectivamente por volta do ano mil e do início do século XII, deixando de lado documentos mais numerosos concernindo, entre esses dois períodos, atores menores. ${ }^{11}$

\section{Oto III em Münster}

O imperador germânico Oto III (996-1002) ofereceu, ao bispo Suitger de Münster, na Westfália (993-1011), relíquias do sangue de São Paulo, patrono de sua catedral, que foram encerradas em uma peça de xadrez, o rei, fabricado em cristal de rocha, talvez no Egito no século IX ou X. Essa doação é indicada por uma inscrição sobre uma placa de prata, datada por volta da primeira metade do século XIII, ou seja, mais de dois séculos após o acontecido. Entre os séculos XIII e XV, a placa foi soldada de forma pouco hábil, sob a peça de xadrez, de cabeça para baixo sobre a tampa de um cibório, ou seja, um recipiente para hóstias consagradas, utilizado como relicário e conservado ainda na catedral. Nessa montagem, a peça dá acesso a sua abertura, situada em sua base, quando se move a dobradiça da tampa cônica que a encima, mas ela não tem mais sentido por si só [fig. 1, pág. 247]. ${ }^{12} \mathrm{Na}$ virada do ano mil, no entanto, esse rei de cristal era certamente identificado como um objeto lúdico e profano que, reconhecido

\footnotetext{
${ }^{10}$ Ver, a respeito de outros objetos, BUC, Philippe. Conversion of objects. Viator. Medieval and Renaissance studies. Berkeley/Los Angeles: University of California Press, 28, 1997, p. 99-144, e os documentos reunidos por SCHRAMM, Percy Ernst. Herrschaftszeichen: gestiftet, verschenkt, verkauft, verpfändet. Belege aus dem Mittelalter. Göttingen: Vandenhoeck \& Ruprecht, 1957.

${ }^{11}$ Ver CORDEZ, Philippe. Images ludiques et politique féodale. Les matériels d'échecs dans les églises du $11^{\mathrm{e}}$ siècle. In: DAHHAOUI, Yann, ORTALLI, Gherardo (dir.). Tempus ludendi. Chiesa e ludicità nella società tardo-medioevale (sec. XII-XV) = Ludica. Annali di storia e civiltà del gioco. Roma: Viella, 13-14, 2007-2008, p. 115-136. Aprofundo, aqui, o estudo de uma parte dos casos apresentados neste artigo.

12 "Inclusvm sancti latet hic de sanguine Pavili, Cesar Suitchero quod pontifici dedit Oddo". Ver, a respeito do objeto, JÁSZAI, Géza. Die Domkammer der Kathedralkirche Sankt Paulus in Münster. Kommentare zu ihrer Bilderwelt. Münster: Kapitel, 1991, p. 16 et 77-78. A relíquia está envolta em um tecido vermelho luminoso, que atrai o olhar através do cristal transparente: ele data, sem dúvida, do século XVII ou XVIII, mas pode ter substituído um outro, mais antigo. Agradeço a Gia Toussaint pela discussão a esse respeito.
} 
como uma imagem de rei, não deixaria de remeter a seu doador imperial. Ora, um mestre-escola de uma igreja da cidade evoca, por volta de 1500, um liber sive rotulus fraternitatis ("livro ou rolo de fraternidade") da catedral, provavelmente do século XII, no qual figuraria a menção Ottonis imperatoris, fratris nostri. Este poderia bem ser Oto III, que se teria associado em comunidade de oração à catedral de Münster quando de uma passagem pela cidade, provavelmente em 997. ${ }^{13}$ Esse tipo de associação fraternal, prometendo uma assistência recíproca sob a forma de orações, destinada a durar após a morte dos parceiros, era um acordo por contrato reforçado por um ritual de compromisso. Os soberanos recorriam a ela para reforçar seus laços com as comunidades monásticas ou canônicas, oferecendo-lhes, por vezes, objetos preciosos, cruzes, coroas, ou, sobretudo, manuscritos onde poderiam ser figurados como soberanos: $:^{14}$ esses objetos e essas imagens deveriam substituir sua presença, em uma época na qual a realeza era itinerante e tratava de multiplicar os símbolos de representação. ${ }^{15}$

O laço manifestado entre o imperador e a catedral de Münster pelo dom da imagem real tornou-se simbolicamente mais íntimo ainda quando a peça foi ocada para a introdução do sangue de São Paulo, o apóstolo convertido e patrono da catedral. Graças a essa operação, sem dúvida tecnicamente delicada, ${ }^{16}$ a relíquia irrigava, por assim dizer, o corpo do imperador que a protegia, por sua vez, assim como Oto III, tornado "irmão" dos cônegos de Münster, velaria sobre eles, beneficiando-se, ao mesmo tempo, do prestígio de sua vocação a Deus. A inclusão da relíquia na peça do rei simbolizava a inclusão do imperador na comunidade. Ela se valia da transparência do cristal de rocha, de acordo com a interpretação

\footnotetext{
${ }^{13}$ Ver PRINZ, Joseph. Prebenda regis. In: SCHRÖER, Alois (dir.). Monasterium. Festschrift zum 700jährigen Weihegedächtnis des Paulus-Domes zu Münster. Münster: Regensberg, 1966, p. 511-545, em particular, p. 522 e p. 540, n. 131, p. 537-538 sobre o objeto, a cotejar com a revisão de GROTEN, Manfred. Von der Gebetsverbrüderung zum Königskanonikat. Zur Vorgeschichte und Entwicklung der Königskanonikate an den Dom- und Stiftskirchen des deutschen Reiches. Historisches Jahrbuch. München: Alber, 103, 1983, p. 1-34, p. 7-8.

${ }^{14}$ Ver, a respeito das associações fraternais de soberanos com comunidades monásticas nos séculos IX-XI, WAGNER, Wolfgang Eric. Die liturgische Gegenwart des abwesenden Königs. Gebetsverbrüderung und Herrscherbild im frühen Mittelalter. Leiden: Brill, 2010.

${ }^{15}$ Ver, a respeito dessa evolução, KRÄNZLE, Andreas. Der abwesende König. Überlegungen zur ottonischen Königsherrschaft. Frühmittelalterliche Studien. Berlim: de Gruyter, 31, 1997, p. 120-157; ZOTZ, Thomas. Die Gegenwart des Königs. Zur Herrschaftspraxis Ottos III. und Heinrichs II. In: SCHNEIDMÜLLER, Bernd, WEINFURTER, Stefan (dir.). Otto III.-Heinrich II. Eine Wende? Stuttgart: Thorbecke, 1997; 2000, p. 349-386.

${ }^{16}$ A perfuração e o ocamento do cristal só foram praticados de forma regular no Ocidente a partir dos séculos XII-XIII. Ver HAHNLOSER, Hans Robert, BRUGGER-KOCH, Susanne. Corpus der Hartsteinschliffe des 12.-15. Jahrhunderts. Berlim: Deutscher Verlag für Kunstwissenschaften, 1985, p. 14-17.
} 
alegórica dessa matéria: para o enciclopedista Rabano Mauro, no início do século IX, e para os que nele se apoiaram, o cristal é água congelada e endurecida e significa o sacramento do batismo, a firmeza dos anjos e a encarnação do Senhor. ${ }^{17}$ O objeto se inscreve, enfim, na categoria por então ainda recente dos relicários antropomórficos ${ }^{18}$ e constitui um caso precoce de reemprego de um objeto em cristal oriental. ${ }^{19}$ Ele inaugura um tipo de dispositivo que possibilita a visão do interior do relicário e que conheceria um grande sucesso. ${ }^{20}$

\section{0 ambão de Henrique II e o império germânico em Aix-la-Chapelle}

A pouco mais de duzentos quilômetros ao sudoeste de Münster, na igreja de Santa Maria de Aix-la-Chapelle, capela dos imperadores germânicos desde Carlos Magno, um ambão doado pelo rei Henrique II (1002-1024) arvora uma série de peças de xadrez [fig. 2, pág. 248]. ${ }^{21}$ Esse púlpito litúrgico se organiza

17 "Crystallo aliquando significat baptismi sacramentum, aliquando firmitatem sanctorum angelorum, aliquando etiam incarnationem Dominicam. [...] Crystallum (sicut dictum est) ex aqua congelascit et robustum fit". HRABANUS MAURUS. De Universo. L. 17, cap. 9, ed. Paris: Migne, 1852 (PL 111), col. 472.

${ }^{18}$ Ver FRICKE, Beate. Ecce fides. Die Statue von Conques, Götzendienst und Bildkultur im Westen. München: Fink, 2007, p. 42-45. A respeito do busto relicário de São Paulo da catedral de Münster, do terceiro quartel do século XI, ver FALK, Brigitta. Bildnisreliquiare: Zur Entstehung und Entwicklung der metallenen Büsten- und Halbfigurenreliquiare im Mittelalter. Aachener Kunstblätter. Aachen: Museumsverein, 59, 1991-1993, p. 99-238, n. 27, p. 162-165.

${ }^{19}$ Eles são mais numerosos depois da pilhagem do palácio fatimida do Cairo entre 1061 e 1069 . Ver SHALEM, Avinoam. Islam christianized. Islamic portable objects in the medieval church treasuries of the Latin West. Frankfurt am Main: Peter Lang, 1996 (Ars Faciendi, 7); ed. rev. 1998, p. 56-71; MAKARIOU, Sophie. Le cristal de roche islamique et ses avatars liturgiques dans l'Occident roman. Les Cahiers de Saint-Michel de Cuxa. Codalet: Association culturelle de Cuxa, 37, 2006, p. 239-247; sobre a pilhagem, Idem; MARTINEZ-GROS, Gabriel. Le trésor du palais fatimide du Caire: inventaire du profane, mécanisme de dispersion et pieuse conservation. Les Cahiers de Saint-Michel de Cuxa. Codalet: Association culturelle de Cuxa, 40, 2010, p. 193-202.

${ }^{20}$ Relicários em cristal de rocha que permitem a visão de um tecido vermelho, expressando, como aqui, a ideia de inclusão, são atestados por volta de 1050, enquanto que aqueles que permitem a visão direta das relíquias só aparecem nos anos 1160 ou 1170. Ver DIEDRICHS, Christof L. Vom Glauben zum Sehen: die Sichtbarkeit der Reliquie im Reliquiar. Ein Beitrag zur Geschichte des Sehens. Berlim: Weißensee-Verlag, 2001, p. 10 et 47; TOUSSAINT, Gia. Blut oder Blendwerk? Orientalische Kristallflakons in mittelalterlichen Kirchenschätzen. In: WENDLAND, Ulrike (dir.). ... das Heilige sichtbar machen. Domschätze in Vergangenheit, Gegenwart und Zukunft. Regensburg: Schnell und Steiner, 2010, p. 107-120.

${ }^{21}$ Ver, sobre o móvel, SCHOMBURG, Silke. Der Ambo Heinrichs II. im Aachener Dom. Tese de doutorado, Technische Hochschule, Aachen, 1998, p. 85-97. Sobre as peças de xadrez, MATHEWS, Karen Rose. Expressing political legitimacy and cultural identity through the use of spolia on the ambo of Henry II. Medieval encounters. Jewish, Christian, and Muslim culture in confluence and dialogue. Leiden: Brill, 5, 1999, p. 156-183. Ver também, sobre as peças, WENTZEL, Hans. Das Byzantinische Erbe der ottonischen Kaiser. Hypothesen über den Brautschatz der Theophano. Aachener Kunstblätter. Aachen: Museumsverein, 40, 1971, p. 15-39 et 42, 1973, p. 11-96, aqui 
em três painéis encurvados. O mais importante, no centro, apresenta nove compartimentos dispostos em um quadrado e os outros dois painéis comportam três compartimentos retangulares sobrepostos. O conjunto é recoberto por placas de metal; as bordas que formam esse quadriculado são ornadas com trabalhos de ourivesaria e com pedras duras. Os cinco compartimentos centrais do painel principal desenham uma cruz, cujo centro era, ao que tudo indica, marcado por um grande camafeu antigo figurando uma águia, hoje no Kunsthistorisches Museum de Viena. ${ }^{22}$ As quatro pontas dessa cruz abrigam vasos de cristal de rocha e de ágata, cuja embocadura está virada para baixo, para a superfície ocada da alma de madeira, de forma que a luz os atravesse e que eles se assemelhem a grandes pedras preciosas. Imagens dos quatro evangelistas em relevo, em ouro, ocupam os ângulos.

As vinte e sete peças de xadrez são engastadas ao redor dos vasos de pedra nos quatro compartimentos que constituem os braços da cruz. Elas são talhadas em dois tipos de pedra, uma ágata rajada e uma calcedônia leitosa e cinza, que distinguiam, sem dúvida, originalmente, dois campos opostos. Sua repartição apresenta, no estado atual, uma disposição coerente, com uma média de seis a oito peças por compartimento. As dezesseis peças principais se dispõem nos ângulos dos campos, enquanto os onze peões ocupam posições intermediárias. Quando se identificam as peças de acordo com o testemunho, um pouco anterior, do poema conservado em Einsiedeln, mosteiro que também se beneficiava dos favores dos imperadores Oto III e, em seguida, Henrique II, ${ }^{23}$ pertencendo, pois, ao mesmo meio cultural, pode-se observar que o eixo vertical da cruz é ocupado por reis ou rainhas nas extremidades superior e inferior e por condes (comiti) na proximidade do cruzamento, enquanto o eixo horizontal é habitado por quatro marqueses (marchi), acima de quatro cavaleiros (equi). ${ }^{24}$ Há, sem dúvida, que contar com importantes variações nesse posicionamento, uma vez que o ambão sofreu várias modificações e restaurações ao longo dos séculos. ${ }^{25}$ Mas a distinção

1971, p. 27 et 1973, p. 62; KLUGE-PINSKER, Antje. Schach und Trictrac, op. cit., p. 34-35 e 46.

${ }^{22}$ O camafeu é dotado de um engaste atribuído a Milão do terceiro quartel do século XVI e, portanto, deve ter deixado Aix-la-Chapelle ao mais tardar por volta dessa época; ele é atestado em Viena desde 1750 e foi substituído no ambão por um vaso de vidro. Ver ZWIERLEIN-DIEHL, Erika. Magie der Steine. Die antiken Prunkkameen im Kunsthistorischen Museum. Wien: Brandstätter, 2008, p. 84-91.

${ }^{23}$ Ver a seis cartas de Oto III e as três de Henrique II em http://www.klosterarchiv.ch [29/03/2011].

${ }^{24}$ Um quinto conde, embaixo, à esquerda, onde se esperaria um rei ou uma rainha, foge à regra.

${ }^{25} \mathrm{O}$ ambão foi reinstalado no novo coro construído em 1414, parcialmente desmontado e colocado ao abrigo durante as guerras de religião do século XVI, e depois sofreu danos ainda maiores 
entre as peças de xadrez e as outras pedras duras relegadas às bordas deve remontar à disposição original e confirma um estatuto específico. As peças são fixadas perpendicularmente ao ambão: fazendo as vezes de um tabuleiro, o alinhamento das peças se faz sobre o motivo da cruz. Este motivo se sobrepõe, ademais, ao corpo daquele que se coloca atrás do ambão. Qual poderia ser o sentido de um tal dispositivo na doação de Henrique II?

Uma inscrição ao longo das bordas superior e inferior do ambão indica que Henrique II o ofereceu à Virgem custeando-o com seus próprios bens e o qualifica como rex, e não ainda como imperador. ${ }^{26}$ Henrique II foi coroado rei da Francia oriental em Mainz, em julho de 1002, pouco depois da morte súbita do jovem Oto III. A sucessão foi difícil, pois nada havia sido preparado. O novo rei, que tinha se apoderado das insígnias da coroação no cortejo que levava o corpo de Oto III da Itália para Aix-la-Chapelle, teve sobretudo que defender sua legitimidade face à aristocracia. Ele recolheu homenagens de uns e de outros viajando através do reino, chegando finalmente a Aix-la-Chapelle, onde sua entronização ocorreu em 8 de setembro, dia da Natividade da Virgem. A doação do ambão pode ter sido concebida nessa ocasião, a partir de materiais herdados de Oto III. Henrique II retornou regularmente a Aix-la-Chapelle antes de sua sagração como imperador romano-germânico em Roma, em 1014. Provavelmente em 1006 ou 1007, após ter sido coroado rei dos lombardos em Pávia, em 1004, ele ofereceu os seis relevos de marfim que parecem ter sido acrescentados aos painéis laterais do ambão quando eles já haviam sido terminados. ${ }^{27}$ Esculpidos em Alexandria no século VI, eles devem ter pertencido a um trono logo transportado a Ravena e, em seguida, a Pávia, quando os lombardos conquistaram o exarcado bizantino - e ele se tornaria aí um símbolo do Reino da Itália. Vendo que sua pretensão à soberania italiana estava vacilante, Henrique II levaria esses elementos e os integraria a seu ambão de Aix-la-Chapelle. As figuras pagãs e profanas desses painéis de marfim faziam as vezes, provavelmente, de metáforas de um hino mariano bizantino, reforçando outros empréstimos de práticas soberanas do império do Oriente: a organização em caixotões e a forma trilobada do ambão foram de fato tomadas de preceden-

quando da ocupação francesa: parece que, por então, a maioria das pedras que o ornamentavam foram perdidas. Ele foi restaurado em 1816-1817 e depois nos anos 1930: sete peões foram então refeitos e cinco peças encontradas no tesouro da catedral foram reintegradas. Ver SCHOMBURG, Silke. Der Ambo, op. cit., p. 18-31 e 91.

26 "Hoc opus ambonis / auro gemmisque micantis / Rex pius Heinricus / celaestis honoris anhelus / Dapsilis ex proprio / tibi dat sanctissima virgo / Quo prece summa / tua sibi merces fiat usia".

${ }^{27}$ Henrique II tem sua presença atestada em Aix-la-Chapelle em 1002, 1003, 1005, 1006, 1007 e várias vezes após 1014. Ver ZOTZ, Thomas. Die Gegenwart, op. cit., p. 384. 
tes em mármore que o futuro Henrique II havia podido observar em Ravena, enquanto, em Santa Sofia de Constantinopla, um móvel como esse entrava em cena quando das coroações imperiais. ${ }^{28} \mathrm{Na}$ borda superior do ambão, o banzo do próprio púlpito, suporte dos Evangelhos, era, ao que parece, constituído por uma sítula de marfim reutilizada, um vaso litúrgico octogonal como a própria capela imperial. Vê-se, no registro inferior, uma série de guardiões armados frente às portas de cidades e, acima, uma sequência de clérigos e o imperador: também lá, os poderes clerical, militar e imperial estão associados. ${ }^{29}$

O dom do ambão à Virgem manifestava, assim, o acesso de Henrique II à realeza, inicialmente germânica, em 1002, depois italiana, em 1004. Nesse contexto, a disposição das peças de xadrez aparece como a afirmação de um programa de governo: depois de ter percorrido o reino para recolher a homenagem dos nobres, Henrique II os faz representar através de suas peças de xadrez em um estado de subordinação ao símbolo real e triunfante da cruz gemada, sobre um móvel que servia à pregação do Evangelho e que estava associado à sua própria pessoa. Tal imagem mobilizava, por um lado, um saber escrito sobre o corpo do Cristo e sobre sua significação eclesiológica, que Henrique II dominava, certamente, por ter estudado nas escolas catedrais de Hildesheim e de Ratisbona e que ele adaptava, desse modo, aos interesses do reino. ${ }^{30}$ Seu reinado, de fato, caracterizou-se por uma assimilação da soberania a um encargo eclesiástico, ${ }^{31}$ o que é regularmente

${ }^{28}$ Ver BREUER, Hendrik. Antike Götter und ein byzantinisches Marienlob. Die spätantiken mythologischen Elfenbeine der Kanzel Heinrichs II. im Dom zu Aachen. Analecta Coloniensia. Köln: Erzbischöfliche Diözesan- und Dombibliothek, 5, 2005, p. 147-200; LEPIE, Hertha, MÜNCHOW, Ann. Elfenbeinkunst aus dem Aachener Domschatz. Petersberg: Imhof, 2006, p. 26-57; sobre as relações com os ambões bizantinos, ver DOBERER, Erika. Studien zu dem Ambo Kaiser Heinrichs II. im Dom zu Aachen. In: Karolingische und ottonische Kunst. Werden, Wesen, Wirkung. Wiesbaden: Steiner, 1957, p. 308-359, em esp. p. 344 e 357.

${ }^{29}$ Ver SCHULZ-REHBERG, Rose-Marie. Die Aachener Elfenbeinsitula. Ein liturgisches Gefäss im Spannungsfeld von Imperium und Sacerdotium. Eine kunst-historische Analyse. Münster: Monsenstein und Vannerdat, 2006, p. 32-33 e 125; LEPIE, Hertha, MÜNCHOW, Ann. Elfenbeinkunst, op. cit., p. 58-75.

${ }^{30}$ Ver, a respeito da história dessa ideia e de sua aplicação à soberania, DE LUBAC, Henri. Corpus Mysticum. L'Eucharistie et l'Église au Moyen Âge. Étude historique. Paris: Aubier, 1944; 1949; Paris: Cerf, 2009, p. 14-16 sobre a assimilação do corpo do Cristo e da Igreja durante a Antiguidade e a Alta Idade Média; KANTOROWICZ, Ernst H. The king's two bodies. A study in mediaeval political theology. Princeton: University Press, 1957; STRUVE, Tilman. Die Entwicklung der organologischen Staatsauffassung im Mittelalter. Stuttgart: Hiersemann, 1978.

${ }^{31}$ Ver WEINFURTER, Stefan. Heinrich II. (1002-1024). Herrscher am Ende der Zeiten. Regensburg: Pustet, 1999; 2002; Idem. Authority and legitimation of royal policy and action. The case of Henry II. In: ALTHOFF, Gerd, FRIED, Johannes, GEARY, Patrick (dir.). Medieval concepts of the past. Washington, D.C.: German Historical Institute, 2002, p. 19-37. 
expresso em imagens e em objetos. ${ }^{32}$ Por outro lado, a instalação de peças de xadrez sobre a cruz deveria ser imediatamente compreensível aos membros da aristocracia aos quais Henrique II se dirigia, uma vez que o jogo lhes era aparentemente familiar. Essa concepção do reino como um corpo crístico e real, de quem o soberano seria a cabeça, foi uma vez mais evocado alguns anos mais tarde, quando Henrique II tratava de reorganizar as relações entre as instituições eclesiásticas. Esse texto de motivação (arenga) de uma carta emitida em 1013 ou 1014 à intenção do bispo de Estrasburgo é uma variação do programa tornado manifesto pelo painel central do ambão:

Como a forma do corpo humano foi criada segundo a ordem racional de Deus todopoderoso, de tal maneira que os membros menores são submetidos à cabeça e governados por ela como por um chefe, nós pensamos que não é incongruente submeter segundo esse modelo certas igrejas menores a outras que são maiores; e nós julgamos que isto não contraria de forma alguma a vontade do rei dos reis, que sabia separar segundo uma ordem admirável a soberania celeste e a terrestre. ${ }^{33}$

\section{0 xadrez "de Carlos Magno" e Suger de Saint-Denis}

A abadia de Saint-Denis, perto de Paris, conservou por muito tempo uma série de peças de xadrez em marfim excepcionais pelo tamanho e pelas figuras [fig. 3, pág. 249]. O processo verbal de seu depósito no Cabinet des Antiques, na origem do atual Département des monnaies, médailles et antiques da Bibliothèque nationale de France, em Paris, feito em 18 de janeiro de 1794, assim os apresenta: "16 pièces d'yvoire - que l'on appelloit anciennement les échecs de Charlemagne parce que l'on supposait qu'elles faisaient partie des présens que

\footnotetext{
${ }^{32}$ Ver KÜNZEL, Susanne. Die Denkmale der Herrschaftstheologie Kaiser Heinrichs II. München: tuduv, 1989; SUCKALE-REDLEFSEN, Gude. Goldener Schmuck für Kirche und Kaiser. In: KIRMEIER, Josef et al. (dir.). Kaiser Heinrich II. 1002-1024. Cat. exp. Bamberg, Stuttgart: Theiss, 2002, p. 78-92; FRICKE, Beate. Ecce fides, op. cit., p. 289-294.

33 "Cum ex rationabili ordine omnipotentis dei corporis humani forma eo modo sit condita, ut quelibet minora membra capiti sint subiecta et ab eo veluti sub quodam duce regantur, non incongruum putavimus ad hanc imitationem quasdam minores ecclesias in regno nostro subdere maioribus et id voluntati regis regum nihil obstare arbitrari sumus, qui celestes atque terrenos principatus miro ordine novit distingere". BRESSLAU, Harry et al. (ed.). Die Urkunden Heinrichs II. und Arduins. 2 t. Hannover: Hahn, 1901-1903; última reimpr. München: MGH, 2001 (MGH, DD H II), n. 277, p. 327; ver BERNHARDT, John William. Der Herrscher im Spiegel der Urkunden: Otto III. und Heinrich II. im Vergleich. In: SCHNEIDMÜLLER, Bernd, WEINFURTER, Stefan (dir.). Otto III.-Heinrich II., op. cit., p. 327-348, p. 344-346; Idem. King Henry II of Germany. Royal self-representation and historical memory. In: ALTHOFF, Gerd, FRIED, Johannes, GEARY, Patrick (dir.). Medieval concepts, op. cit., p. 39-69, p. 56-57.
} 
le calife Aaron Raschild envoya à cet empereur". ${ }^{34} \mathrm{O}$ tema da doação por Harum al-Rashid, que aparece neste documento, não era, provavelmente, antigo e visava a explicar a aparência exótica das figuras aproximando-as da bem-conhecida troca de mensageiros entre o imperador carolíngio e o califa abássida. ${ }^{35}$ Mas a atribuição a Carlos Magno é anterior: ela é atestada desde a primeira menção das peças em Saint-Denis, em 1505, quando um inventário menciona "Ung jeu complet d'eschetz d'yvire [...], qui estoient à Charles Maigne" ${ }^{36}$

Atribuídos à Itália meridional e ao fim do século XI, essas peças, que tomam seus motivos e formas à Roma antiga (quadrigas), ao Império Romano-Germânico e a Bizâncio (rei e rainhas), à Índia e ao Islã (elefantes), mas também ao mundo anglo-normando (soldados e cavaleiros), exprimem a situação política particular dessa região, que era então conquistada pelos normandos, conduzidos principalmente pelo duque Robert de Hauteville, chamado "Guiscard", ou o Prudente, que nutria ambições imperiais, e que morreu em 1085. Não iremos aprofundar aqui a questão da primeira história dessas peças de xadrez. Mas a retomamos para explicar sua chegada a Saint-Denis, quando os reis da França Filipe II Augusto e Filipe III estiveram, respectivamente, de passagem por Salerno, em 1190, e por Palermo, em 1271. ${ }^{37}$ Essas hipóteses mostram bem a questão dos laços pessoais e históricos entre a Itália meridional e a abadia de Saint-Denis, mas elas não esclarecem a

34 " 16 peças de marfim - que se chamavam antigamente de xadrez de Carlos Magno porque se supunha que fizessem parte dos presentes que o califa Aaron Raschild enviou a esse imperador". Apud MONTESQUIOU-FEZENSAC, Blaise de; GABORIT-CHOPIN, Danielle. Le trésor de SaintDenis. Inventaire de 1634. 3 t., Paris: Picard, 1973-1977, t. 2, Documents divers, 1977, p. 214.

35 Ver SENAC, Philippe. Les carolingiens et le califat abbasside (VIIIe-IXe siècles). Studia Islamica. Paris: Maisonneuve-Larose 95, 2002, p. 5-35. As peças tinham sido regularmente descritas como orientais desde o século XVII. Ver MONTESQUIOU-FEZENSAC, Blaise de; GABORITCHOPIN, Danielle. Le trésor, op. cit., t. 2, p. 214.

36 "Ung jeu complet d'eschetz d'yvire et trente table aussi d'yvire, qui estoient à Charles Maigne" ("Um jogo completo de xadrez de marfim e trinta mesas também de marfim que eram de Carlos Magno "), citado ibidem, p. 213. O inventário de 1634 distingue o jogo de xadrez "de Carlos Magno" das "mesas", precisando, quanto a elas: "trente tables d'ivoire, jeu de tables, taillées à plusieurs personnages et bestes" ("trinta mesas de marfim, jogo de mesas, talhadas com vários personagens e animais"). Essas mesas de jogo, as únicas que teriam sido conservadas em uma igreja, que eu saiba, não aparecem mais na sequência. Sobre esse tipo de objeto, ver KLUGEPINSKER, Antje. Schach und Trictrac, op. cit.

37 Ver PASTOUREAU, Michel. L'échiquier de Charlemagne, op. cit., p. 34-36; SPECIALE, Lucinia. Il gioco dei Re: intorno agli "Scacchi di Carlomagno". In: QUINTAVALLE, Arturo Carlo (dir.). Medioevo: la chiesa e il palazzo. Milão: Electa, 2007, p. 238-248, p. 245-246. Esses estudos se baseiam em GOLDSCHMIDT, Adolph. Die Elfenbeinskulpturen aus der romanischen Zeit. XI.XIII. Jahrhundert. 2 t. Berlim: Deutscher Verlag für Kunstwissenschaft, 1923-1926; 1972-1975, t. 2, n. 161-162, 164-165, 167, 170-175, p. 46-48, pl. LIX-LXII. Ver também KLUGE-PINSKER, Antje. Schach und Trictrac, op. cit., p. 17-26. 
atribuição a Carlos Magno, que é, no entanto, o principal indício de que dispomos, além de subestimarem o alcance simbólico e político de tais peças de xadrez.

Uma outra pista deve ser explorada, a do abade Suger (1122-1151), ${ }^{38}$ que esteve bem mais implicado na política de seu tempo do que os demais abades de Saint-Denis. Nascido em 1081, educado em Saint-Denis ao mesmo tempo que o futuro rei Luís VI (1108-1137) de quem se tornou conselheiro, Suger teve, desde cedo, a oportunidade de se familiarizar com a chancelaria real francesa, assim como com os costumes diplomáticos da Santa Sé, ou ainda com as qualidades da administração anglo-normanda. Ainda simples monge, ele se envolveu no grande projeto de fazer oficialmente de Saint-Denis uma abadia e uma necrópole reais, o que ela já era, oficiosamente, desde a época merovíngia. ${ }^{39}$ Tratava-se, ao mesmo tempo, de contribuir para a consolidação do reino de França, então enfraquecido politicamente e limitado de fato ao domínio real, ou seja, à Île-deFrance. Em 1108 ou 1109, Suger estabeleceu, ou pelo menos encorajou que se estabelecesse, um ritual comemorando o aniversário de morte do rei Dagoberto (622-638), tido como fundador da igreja e o primeiro rei que lá foi enterrado: foi ele que redigiu a carta. Em 1120, ele esteve implicado na composição do ato pelo qual Luís VI depositou em Saint-Denis a coroa de seu pai. Em 1124, então abade havia dois anos, Suger redigiu um novo ato dando a seu pensamento político um viés ainda mais audacioso: o rei nele aparece, em sua função de conde de Vexin, como vassalo dos santos mártires da abadia. ${ }^{40}$ Enquanto os grandes vassalos se agrupavam em torno de Luís VI para rebater um ataque do imperador germânico Henrique $\mathrm{V}$, o poder real francês era apresentado como dependendo diretamente dos santos e de Deus. O poder da abadia se via igualmente reforçado à cabeça da Igreja da França e, portanto, em relação direta com o papado. Suger radicalizou ainda mais essas ideias em um falso diploma de Carlos Magno, elaborado, muito provavelmente, entre 1124 ou 1127 e 1129 e tido como o ato fundador da

\footnotetext{
${ }^{38}$ Ver GABORIT-CHOPIN, Danielle (dir.). Le trésor de Saint-Denis. Cat. exp. Musée du Louvre. Paris: Réunion des Musées Nationaux, 1991, p. 130-141, p. 141.

${ }^{39}$ Ver, para o que se segue, GASPARRI, Françoise. La politique de l'abbé Suger de Saint-Denis à travers ses chartes. Cahiers de civilisation médiévale, 46, 2003, p. 233-245. O papel de Suger foi muitas vezes exagerado, tanto no que diz respeito à história da França quanto no que diz respeito à história da arte. Ver, respectivamente, as correções de GROSSE, Rolf, Saint-Denis zwischen Adel und König. Die Zeit vor Suger (1053-1122). Stuttgart: Thorbecke, 2002 (Beihefte der Francia, 57), e o comentário de REUDENBACH, Bruno. Panofsky und Suger von St. Denis. In: Idem (dir.). Erwin Panofsky.Trad. fr. Panofsky et Suger de Saint-Denis. Berlim: Akademie Verlag, 1994, p. 109-122 In: ESPAGNE, Michel (dir.). Histoire et théories de l'art. De Winckelmann à Panofsky. Paris: PUF, 1994, p. 137-150.

${ }^{40}$ Sobre a história anterior dessa ideia, ver GROSSE, Rolf. Saint-Denis zwischen Adel und König, op. cit., p. 30-35.
} 
vassalidade do rei em relação à abadia. O imperador carolíngio é aí colocado em cena se despojando, no altar dos mártires, das "insígnias e ornamentos do reino de França", ${ }^{41}$ antes de proclamar, frente aos grandes do reino, que ele deixava aos santos o regnum franciae do qual ele teria sido apenas o defensor, a fim de que eles fossem os guardiões e os senhores junto a Deus. Entre outras medidas, Carlos Magno proibia seus sucessores de se fazerem coroar em outro lugar que Saint-Denis. Essa reivindicação assume todo seu sentido em um contexto de rivalidade com a abadia de Saint-Rémi de Reims: em 1108, Luís VI havia sido coroado, com urgência, na catedral de Orléans, mas os dois reis precedentes, Henrique I e Filipe I, haviam sido coroados em Reims, em 1027 e em 1059. Essa concorrência explica também porque o arcebispo de Reims aparece à frente das vinte testemunhas do falso diploma de Carlos Magno, logo após o imperador. ${ }^{42}$

Ora, a exibição das peças de xadrez de aspecto propriamente imperial, reputadas haverem sido entregues por Carlos Magno sobre o altar dos mártires de Saint-Denis no ato solene evocado pelo falso documento, materializava precisamente essa ideia de que Carlos Magno teria confiado seu reino à abadia: o jogo "de Carlos Magno" deve ter contado entre as "insígnias e ornamentos do reino" evocados na falsa carta e foi, certamente, concebido como tal por Suger nas mesmas circunstâncias, ou seja, provavelmente entre 1124 e 1129. O abade deveria julgar plausível e compreensível esse dom de peças de xadrez por Carlos Magno: de fato, as doações de materiais de xadrez a igrejas são regularmente atestadas ao longo do século XI. Em 1096, por exemplo, às vésperas de partir em

41 "Sanctissime domine Dionysi hiis regni Franciae regiis insigniis et ornamentis libenter me spolio, ut deinceps eius regale habeas [...]". MÜHLBACHER, Engelbert (ed.). Die Urkunden der Karolinger, t. 1. Die Urkunden Pippins, Karlmanns und Karls des Grossen. Hannover: Hahn, 1906; última reimpr. München: MGH, 1991 (MGH, DD Kar, 1), n. 286, p. 428-430, p. 429. O texto é conhecido por uma edição do século XVII. Ver GROTEN, Manfred. Die Urkunde Karls des Großen für St.-Denis von 813 (D 286), eine Fälschung Abt Sugers? Historisches Jahrbuch. München: Alber, 108, 1988, p. 1-36, p. 8-9 para a data; GASPARRI, Françoise. La politique de l'abbé Suger, op. cit., p. 240-243, trad. da passagem p. 240; CLAUSEN, Jens Peter. Suger, faussaire de chartes. In: GROSSE, Rolf(dir.). Suger en question. Regards croisés sur Saint-Denis. München: Oldenbourg, 2004, p. 109-116, p. 112-114.

${ }^{42}$ Sobre a concorrência entre Saint-Denis e Saint-Rémi ao longo do século XII, ver KRAMP, Mario. Kirche, Kunst und Königsbild. Zum Zusammenhang von Politik und Kirchenbau im capetingischen Frankreich des 12. Jahrhunderts am Beispiel der drei Abteien Saint-Denis, Saint-Germain-desPrés und Saint-Remi/Reims. Weimar: Verlag und Datenbank für Geisteswissenschaften, 1995, em particular p. 289-290; LINSCHEID-BURDICH, Susanne. Suger von Saint-Denis. Untersuchungen zu seinen Schriften Ordinatio, De consecratione, De administratione. München: Saur, 2004, estuda, nas páginas 88-98, o uso que faz Suger da Historia dedicationis ecclesiae sancti Remigii, redigida pelo monge Anselmo de Saint-Rémi após a consagração de 1049, em seu Scriptum consecrationis ecclesiae sancti Dionisii (1144 ou 1145), onde ele parece se dedicar a ultrapassar seu modelo. 
cruzada para Jerusalém, onde iria desempenhar um papel de primeira importância na tomada da cidade em 1099, o duque Godofredo de Bulhões (1061-1100) havia oferecido um jogo de cristal à abadia beneditina de Saint-Hubert nas Ardennes, significando, assim, que ele remetia a Deus o destino de sua tropa antes de se lançar em uma empresa que se anunciava perigosa: é o que expressa, em uma única frase, a crônica da abadia, redigida menos de dez anos depois, entre 1098 e 1106. ${ }^{43}$ Nesse mesmo ano de 1096, o conde Wiprecht de Groitzsch (por volta de 1050-1124), quando da consagração da igreja do mosteiro beneditino de Sankt-Jakobus de Pegau, próximo a Leipzig, na Saxônia, que ele havia fundado ao retornar de uma peregrinação a Roma e a Compostela para expiar violentos feitos de guerra, teria ofertado várias peças de xadrez em cristal e marfim, destinadas "a ornar o púlpito". Esse gesto, registrado nos anais locais, redigidos por volta de 1155, é testemunho, provavelmente, da fama do dispositivo do ambão de Aix-la-Chapelle, adaptado a uma nova situação: ao associar as peças de xadrez ao móvel sobre o qual se liam os Evangelhos, Wiprecht manifestava sua vontade de se separar de seu passado militar, ao mesmo tempo em que reafirmava seu título de soberano, ainda mais porque havia herdado, provavelmente, as peças de seu sogro, o rei Vratislav II da Boêmia (1085-1092), igualmente implicado na nova fundação. ${ }^{44}$

Como Suger, antes de conceber tal dom, havia adquirido essas peças de xadrez? Ele indica, em sua Vida de Luís VI, redigida por volta de 1144, ter re-

${ }^{43}$ Cantatorium sancti Huberti. HANQUET, Karl (ed.). La chronique de Saint-Hubert dite "Cantatorium". Nouvelle édition. Bruxelas: Kiessling, 1906, p. 208: "Nec multo post dux Hierosolimam vadens, ludum unum christallinarum alearum nobis transmittens, multos secum nobiles et religiosos abduxit". Trad. fr. ROBAUX DE SOUMOY, Aimé Louis Philémon de. Chronique de l'abbaye de Saint-Hubert dite Cantatorium. Bruxelas: Méline Cans et Cie, 1847; Bruxelas: Culture et Civilisation, 1982, p. 135: "Peu de temps après, le duc se mit en route pour Jérusalem, nous envoyant un jeu en cristal; il emmena avec lui un grand nombre de seigneurs et de religieux" ("Pouco tempo depois, o duque tomou o caminho para Jerusalém, nos enviando um jogo em cristal; ele levou consigo um grande número de senhores e de religiosos").

${ }^{44}$ Para a doação de Vratislav: "[...] tabula scacorum auro redimita, lapidibus etiam eburneis et cristallinis artificiose sculptis [...]". Quando da consagração: "Dedit praeterea ad ornatum pulpiti lapides scachorum cristallinos et eburneos sculpturis insignes". Ver PERTZ, Georg Heinrich (ed.). Annales Pegavienses. Hannover: Hahn, 1859 (MGH, SS, 16), p. 232-270, p. 240-241; 246. Sobre Wiprecht, ver INNOCENTI, Marco. Wiprecht von Groitzsch. In: BAUTZ, Friedrich Wilhelm, BAUTZ, Traugott (dir.). Biographisch-Bibliographisches Kirchenlexikon. 32 t., Hamm/Nordhausen: Bautz, 1975-2009, t. 22, 2003, col. 1551-1556; versão atualizada: http:/www.bbkl.de/ [07/02/11]. Sobre a fundação do mosteiro, ver VOGTHERR, Thomas. Wiprecht von Groitzsch und das Jakobspatrozinium des Klosters Pegau. Ein Beitrag zur Kritik der Pegauer Annalen. In: Neues Archiv für sächsische Geschichte. Dresde: Baensch, 72, 2001, p. 35-53; BÜNZ, Enno. Wiprecht von Groitzsch und der hl. Jakobus. In: HERBERS, Klaus, BÜNZ, Enno (dir.). Der Jakobuskult in Sachsen. Tübingen: Narr 2007, p. 61-95, p. 82 e 84 sobre o papel de Vratislav para Wiprecht. 
alizado, nos anos que precederam a redação do falso diploma "de Carlos Magno", duas viagens à Itália meridional normanda que podem ter-lhe fornecido a oportunidade: em janeiro de 1121, quando ele encontrou o papa em Apúlia para tratar de "diversos assuntos do reino", antes de se tornar abade, em sua volta, em março de 1122; e, principalmente, após o concílio de Latrão, do qual participou, em março de 1123, quando permaneceu por seis meses na região e visitou os principais santuários. ${ }^{45}$ Ao longo dessas viagens, notadamente a Roma, ele viu edifícios e obras que teve logo a ambição de imitar em Saint-Denis, ${ }^{46}$ e pode ser que ele tenha então escolhido as peças de xadrez sabendo já o que faria com elas. Algumas peças comparáveis, ainda que isoladas, são conhecidas ${ }^{47}$ e a série de Saint-Denis parece ser heterogênea, recomposta a partir de vários conjuntos diferentes, ${ }^{48}$ às quais se juntou uma peça de elefante, maior, mais complexa e mais antiga, de origem indiana. ${ }^{49}$ Isso indica, por um lado, que existiram vários jogos desse tipo na Itália normanda e faz supor, por outro lado, que Suger reuniu o que pôde adquirir e que, na falta de uma série coerente, ele deixaria explicitada, em Saint-Denis, a ideia de um jogo de xadrez prestigioso. A atribuição das peças a Carlos Magno só fez refletir a ambição imperial nelas inscrita desde sua criação. Não há dúvida de que o abade Suger teria frequentado meios onde circulavam tais objetos. Ele deve ter encontrado o futuro rei normando da Sicília, Roger II (1130-1154): a Vida de Suger, redigida pelo monge Guilherme de Saint-Denis nos anos seguintes à morte do abade, depois de 1152 ou 1154, afirma que os dois homens se conheciam, ${ }^{50} \mathrm{e}$ há também uma troca de cartas entre eles conservada

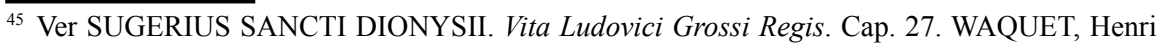
(ed. e trad.). Vie de Louis VI le Gros. Paris: Champion, 1929; Paris: Les Belles Lettres, 1964; 2007, p. 207-208 e 214-217.

${ }^{46}$ Ver GASPARRI, Françoise. Le renouveau de Rome. In: BOS, Agnès, DECTOT, Xavier (dir.). L'architecture gothique au service de la liturgie. Turnhout: Brepols, 2003, p. 43-66.

${ }^{47}$ Ver SPECIALE, Lucinia. Il gioco dei Re, op. cit.

${ }^{48}$ Ver PASTOUREAU, Michel. L'échiquier de Charlemagne, op. cit., p. 58, que distingue "pelo menos três".

49 Ver KÜHNEL, Ernst. Die islamischen Elfenbeinskulpturen. VIII.-XIII. Jahrhundert. 2 t. Berlim: Deutscher Verlag für Kunstwissenschaft, 1971, n. 17, p. 30-31; MAKARIOU, Sophie. Le jeu d'échecs, op. cit., p. 135-136. O objeto é associado às outras peças desde o inventário de 1505: "Ung elephant aussi d'yvire, taillé à plusieurs personnaiges dessus et alentour", citado em MONTESQUIOU-FEZENSAC, Blaise de, GABORIT-CHOPIN, Danielle. Le trésor, op. cit., t. 2, p. 213.

50 "Nonne huic famosissimus rex Sicilie Rogerus litteras misit suplices et deprecatorias, ac munera destinavit?”. GUILLELMUS SANCTI DIONYSII. Sugerii Vita. Ed. e trad. GASPARRI, Françoise. Suger. Euvres. 2 t., Paris: Les Belles Lettres, 1996-2001, t. 2, p. 292-373, p. 310-311: "N'est-il pas vrai que le très célèbre roi de Sicile Roger lui envoya des lettres de prière et de supplication, et lui adressa des cadeaux?" ("Não é verdade que o muito célebre rei da Sicília Roger enviou-lhe cartas de orações e súplicas, e enviou-lhe presentes?"). 
em uma recolha de 188 missivas do tempo em que Suger foi regente do reino de França (1147-1149), compilada por Guilherme ou, em todo caso, por ele utilizada. ${ }^{51}$ Suger afirma, ademais, na narrativa de sua administração da abadia, redigida no final de sua vida, entre 1144 e1149, ter recebido, do conde de Blois, um vaso enviado a este pelo rei Rogério II da Sicília. ${ }^{52}$ Por diversas vezes, Suger soube se aproveitar de suas relações para reunir em Saint-Denis objetos de grande prestígio, como ele mesmo afirma e como testemunham, ainda hoje, seis vasos de aventurina, de cristal, de sardônia e de pórfiro, cujos engastes ele mandou fazer. ${ }^{53}$ Essas aquisições, como a das peças de xadrez, poderiam ser resultado de operações diplomáticas complexas, sobre as quais ele não escreveu tudo. ${ }^{54}$

Suger havia inovado, em relação aos dons precedentes de material de xadrez às igrejas, ao projetar naquele "de Carlos Magno" um passado prestigioso. Esta invenção se inscreve em uma abundante política memorial e o abade buscava colocar em cena, na igreja de Saint-Denis, uma densa rede de marcadores memoriais, objetos ou elementos arquitetônicos que materializavam as reivindicações de sua abadia. ${ }^{55}$ Tendo contribuído a instituir a celebração anual da memória do rei Dagoberto, ele fez, então, restaurar sua cathedra, "sobre a qual, como atesta

${ }^{51}$ Na primavera de 1150, Roger fez saber a Suger que ele estava em boa saúde e pediu-lhe notícias; este encarregou um mensageiro de tratar com o rei a respeito de vários assuntos. Ver NORTIER, Michel. Étude sur un recueil de lettres écrites par Suger ou à lui adressées (1147-1150). Journal des savants. Paris: de Boccard, 2009/1, p. 25-102, p. 76-78.

52 "Lagenam quoque preclaram, quam nobis comes Blesensis Theobaldus in eodem vase destinavit in quo ei rex Siciliae illud transmiserat [...]". SUGERIUS SANCTI DIONYSII. Gesta Sugerii Abbatis. Cap. 34. GASPARRI, Françoise (ed. e trad.). Suger. Euvres, op. cit., t. 1, p. 54-155, p. 154-155: "La superbe aiguière que le comte de Blois Thibaud nous fit parvenir dans le même coffret dans lequel le roi de Sicile la lui avait envoyée [...]" ("O suntuoso jarro que o conde de Blois Thibaud nos fez chegar na mesma caixa na qual o rei da Sicília lho havia enviado [...]").

${ }^{53}$ Ver ibidem, p. 150-155; GABORIT-CHOPIN, Danielle (dir.). Le trésor de Saint-Denis, op. cit., p. $152-155,163-176$ e $183-187$.

${ }^{54}$ Ver o dossiê reconstituído por BEECH, George T. The Eleanor of Aquitaine Vase, William IX of Aquitaine, and Muslim Spain. Gesta. Nova Iorque: International Center of Medieval Art, 32/1, 1993, p. 3-10; Idem. The Eleanor of Aquitaine Vase: Its origins and history to the early twelfth century. Ars Orientalis. Ann Arbor: Department of the History of Art, University of Michigan, 22, 1992, p. 69-79 trata do próprio objeto; resultados retomados em Idem. The Eleanor of Aquitaine Vase. In: WHEELER, Bonnie, PARSONS, John Carmi (dir.). Eleanor of Aquitaine. Lord and lady. Nova Iorque: Palgrave Macmillan, 2003, p. 369-376; igualmente NORTON, Christopher. Bernard. Suger, and Henry I's Crown Jewels. Gesta. Nova Iorque: International Center of Medieval Art, 45/1, 2006, p. 1-14 (ver p. 6-7 e n. 30 a respeito do jarro do conde de Blois).

${ }^{55}$ Ver ALBRECHT, Stephan. Die Inszenierung der Vergangenheit im Mittelalter. Die Klöster Glastonbury und Saint-Denis. München/Berlim: Deutscher Kunstverlag, 2003; GASPARRI, Françoise. Le programme iconographique de l'abbaye de Saint-Denis au XII 'siècle. In: LEMOINE, Michel (dir.). L'image dans la pensée et l'art du Moyen Age. Turnhout: Brepols, 2006, p. 115-134; BURKART, Lucas. Das Blut der Märtyrer. Genese, Bedeutung und Funktion mittelalterlicher Schätze. Köln/Weimar/Wien: Böhlau, 2009, p. 156-196. 
sua antiguidade, os reis dos francos tinham o costume de se sentar para receber a primeira homenagem de seus grandes", como ele lembra na narrativa de sua administração. ${ }^{56}$ Atualmente na Bibliothèque nationale de France [fig. 4, pág. 250], essa cadeira poderia ter sido uma antiga insígnia de cônsul ou sella curulis que o imperador do Oriente Anastásio I teria entregue ao rei Clóvis (por volta de 482-511) ao conferir-lhe essa dignidade, em 508, antes que Clóvis a oferecesse a São Dionísio, escolhido patrono de seu reino recém-convertido. ${ }^{57}$ Suger parece ter feito dela um trono fixo, bloqueando o antigo mecanismo de dobradura e acrescentando um espaldar em forma de frontão, que se inscreve em uma tradição antiga e carolíngia. Essa forma foi também empregada na abadia de Saint-Rémi de Reims nos anos 1130, em um monumento de pedra que emoldurava um trono real, conhecido somente por fragmentos e por uma gravura do século XVIII [fig. 5, pág. 249], ao qual voltaremos mais adiante. ${ }^{58}$ Já foi sugerido que sua renovação poderia estar ligada à afirmação, em Roma, da noção de "cátedra de São Pedro", no contexto da reforma e reafirmação do papado, que acompanhou sua longa querela contra o Império germânico a respeito da investidura dos bispos. De fato, um trono de marfim carolíngio dotado de um espaldar com um frontão desse tipo, provavelmente fabricado para Carlos, o Calvo (843-877), e por ele levado a Roma, onde ingressou em seguida às possessões do papa, foi considerado

56 “Nec minus nobilem gloriosi regis Dagoberti cathedram, in qua, ut perhibere solet antiquitas, reges Francorum, suscepto regni imperio, ad suscipienda optimatum suorum hominia primum sedere consueverant, tum pro tanti excellentia officii, tum etiam pro operis ipsius precio, antiquatam et disruptam refici fecimus". SUGERIUS SANCTI DIONYSII. Gesta Sugerii Abbatis. Cap. 17, op. cit., p. 146-147: "Quant au trône non moins illustre du glorieux roi Dagobert sur lequel, comme l'atteste son antiquité, les rois des Francs, après avoir pris le gouvernement du royaume, avaient coutume de s'asseoir pour recevoir le premier hommage de leurs grands, de vieux et brisé qu'il était nous l'avons fait restaurer tant pour l'excellence d'une telle fonction que pour la valeur de l'œuvre elle-même" ("Quanto ao trono não menos ilustre do glorioso rei Dagoberto sobre o qual, como atesta sua antiguidade, os reis dos francos, após terem assumido o governo do reino, tinham costume de se sentar para receber a primeira homenagem de seus grandes, e que estava velho e quebrado, nós o fizemos restaurar, tanto pela excelência de uma tal função quanto pelo próprio valor da obra ").

${ }^{57}$ Ver HOFFMAN, Volker. Le "Trône de Dagobert" au Cabinet des Médailles de la Bibliothèque nationale. Bulletin de la société de l'Histoire de l'Art français. Paris: Société de l'Histoire de l'Art Français, 2004, p. 9-19. A datação dos diferentes elementos da cadeira permanece incerta. Ver também CORSEPIUS, Katharina. Der Dagobertthron in Saint-Denis als ,profane Reliquie“. In: Idem, MONDINI, Daniela, SENEKOVIC, Darko, SIBILLANO, Lino, VITALI, Samuel (dir.). Opus tessellatum. Modi und Grenzgänge der Kunstwissenschaft. Festschrift für Peter C. Claussen. Hildesheim: Olms, 2004, p. 139-152.

${ }^{58}$ Ver NEES, Lawrence. The Fastigium of Saint-Remi ("the Tomb of Hincmar") at Reims. In: MAXWELL, Robert A. (dir.). Representing history, 900-1300. Art, music, history. University Park, Pennsylvania: The Pennsylvania State University Press, 2010, p. 31-52; 211-221. 
como a cathedra Petri, conservada na igreja de São Pedro [fig. 6, pág. 250]. A atribuição dessa cadeira carolíngia ao apóstolo Pedro, primeiro bispo de Roma e primeiro papa, poderia ter ocorrido em 1130, por ocasião da entronização precipitada do antipapa Anacleto II, cuja eleição deveria fazer frente à de Inocêncio II; ela poderia também ser um pouco anterior, mas só é atestada explicitamente no século XIII. ${ }^{59} \mathrm{O}$ papa Inocêncio II, em exílio na França, logo reconhecido pelo rei Luís VI e pelo imperador Lotário III, foi recebido com grande pompa por Suger e coroado em Saint-Denis, quando das festividades de páscoa em 1131. Ele se dirigiu a Reims naquele mesmo ano, onde sagrou o príncipe Luís. ${ }^{60}$ Qualquer que tenha sido a eventual transferência dessa forma de frontão à cátedra "de Dagoberto", cuja restauração poderia estar ligada à coroação de Inocêncio II em 1131 e ao monumento de Reims, Suger esteve ao longo de toda sua vida em estreito contato com o papado, engajando-se a seu lado no conflito que opunha Roma aos imperadores germânicos relativamente às investiduras dos bispos, ${ }^{61} \mathrm{e}$ ele deveria ser, portanto, sensível às criações simbólicas dos papas. ${ }^{62}$ Sua cátedra "de Dagoberto" materializava, por um lado, a dependência dos reis de França à abadia, através do tema da entronização que o grande selo do rei Luís VII (11371180) também amplificou, no qual ele é apresentado sobre uma cátedra similar, uma inovação que poderia ter tido alguma influência de Suger. ${ }^{63}$ Por outro lado, a analogia tipológica entre a cathedra Dagoberti e a cathedra Petri manifestava a ideia de que Saint-Denis representava a igreja de São Pedro no reino de França: Suger assim afirma em sua Vida de Luís VI que o papa Pascal II, em viagem à França, teria estado, em 1107, em Saint-Denis “como ele teria feito na própria

\footnotetext{
${ }^{59}$ Ver MACCARRONE, Michele. La "Cathedra Sancti Petri” nel medioevo: da simbolo a reliquia. Rivista di storia della Chiesa in Italia. Milão: Vita e Pensiero, 39, 1985, p. 349-447; reimpr. in Idem. Romana ecclesia cathedra Petri. 2 t. Roma: Herder, 1991, t. 2. p. 1249-1373. Sobre o objeto, NEES, Lawrence. A Tainted Mantle. Hercules and the classical tradition at the carolingian court. Filadélfia: University of Pennsylvania Press, 1991; Idem. Audiences and reception of the Cathedra Petri. Gazette des beaux-arts. Paris: Gazette des beaux-arts, 122, 1993, p. 57-72, p. 61-64 para o século XII.

${ }^{60}$ Ver SUGERIUS SANCTI DIONYSII. Vita Ludovici Grossi Regis. Cap. 32. Henri WAQUET (ed. e trad.), op. cit., p. 262-265 et 268-269.

${ }^{61}$ Ver GASPARRI, Françoise. L'abbé Suger de Saint-Denis et la papauté. In: GROSSE, Rolf(dir.). Suger en question, op. cit., p. 69-80, p. 75-78 sobre esses acontecimentos.

${ }^{62}$ Ver, de forma, geral, a respeito destas, STROLL, Mary. Symbols as power. The papacy following the investiture contest. Leiden: Brill, 1991.

${ }^{63}$ Ver BEDOS REZAK, Brigitte. Suger and the symbolism of royal power: The seal of Louis VII. In: LIEBER GERSON, Paula (dir.). Abbot Suger and Saint-Denis. A symposium. Nova Iorque: The Metropolitan Museum of Art, 1986, p. 95-103, e as observações de KRAMP, Mario. Kirche, Kunst und Königsbild, op. cit., p. 142, n. 226.
} 
sé de São Pedro". ${ }^{64} \mathrm{O}$ trono "de Dagoberto" trazia, assim, uma variação para a mensagem do xadrez "de Carlos Magno", ao associar a abadia de Saint-Denis ao reino de França e ao papado de Roma: a afirmação de que o soberano carolíngio teria confiado o reino à abadia reproduzia, de fato, em uma escala reduzida, o tema formulado no século VIII, por meio de uma outra falsificação, a doação do Império do Ocidente à Igreja por Constantino. ${ }^{65}$

O falso ato e as peças de xadrez "de Carlos Magno" exprimiam uma reivindicação provavelmente excessiva que não teve os efeitos esperados: desde 1129 e 1131, contrariando a injunção suposta do imperador carolíngio e arruinando as esperanças de Suger, foi a abadia de Saint-Rémi de Reims, e não Saint-Denis, a escolhida para as coroações sucessivas dos dois filhos de Luís VI, os príncipes Filipe, que morreu precocemente, e em seguida Luís. Essa decepção, terminus ante quem para a datação do empreendimento, marcou uma mudança de orientação na estratégia de Suger, que se voltou para o papa, e não mais para o rei, entre 1129 e $1131,{ }^{66}$ e que concentraria, em seguida, seus esforços na reconstrução de sua igreja. Mas as peças do xadrez permaneceram entre as riquezas da abadia. Seu sucesso, ou pelo menos o ambiente cultural no qual foram recebidas junto com os outros objetos reais de Saint-Denis, parece transparecer na Canção de Rolando anglo-normanda, composta durante o segundo quartel do século XII e que narra o fim de uma longa guerra dirigida por Carlos Magno contra os sarracenos da Espanha. Nela, encontramos o imperador carolíngio sentado sobre um assento em ouro dobrável que evoca o trono "de Dagoberto"; a seu lado, seus cavaleiros jogam xadrez, como em outras canções de gesta, ${ }^{67}$ e a trompa de Rolando, cuja

64 “[...] tanquam ad propiam beati petri sedem [...]”. SUGERIUS SANCTI DIONYSII. Vita Ludovici Grossi Regis. Cap. 10, Henri WAQUET (ed. e trad.), op. cit., p. 54-55 (trad. modificada).

${ }^{65}$ Ver FRIED, Johannes. "Donation of Constantine" and "Constitutum Constantini". The misinterpretation of a fiction and its original meaning. Berlim: De Gruyter, 2007.

${ }^{66}$ Ver GROSSE, Rolf. Saint-Denis und das Papsttum zur Zeit des Abtes Suger. In: Idem (dir.). Die französische Kirche und das Papsttum (10.-13. Jahrhundert). Bonn: Bouvier, 1993, p. 219-238, p. 233-235 para a hipótese de uma ligação entre o fracasso do falso diploma de Carlos Magno e os atos papais de 1129-1131.

${ }^{67}$ Chanson de Roland, v. 115: "faldestoed i unt, fait tut d'or mer", e 110-112: "Sur palies blancs siedent cil cevaler, / as tables jüent pur els esbaneier, / e as eschecs li plus saive e li veill". SHORT, Ian (ed.). In: DUGGAN, Joseph J. (dir.). La chanson de Roland. The song of Roland. The French corpus. 3 t., Turnhout: Brepols, 2005, t. 1, p. I/111-I/270, p. I/115. O motivo dos cavaleiros de Carlos Magno jogando xadrez aparece também em várias passagens da Chanson d'Aspremont, do século XII, elencadas em ADAMS, Jenny. Power play. The literature and politics of chess in the Late Middle Ages. Filadélfia: University of Pennsylvania Press, 2006, p. 157, n. 1. Ver ainda em Garin de Monglane, do século XIII: JONIN, Pierre. La partie d'échecs dans l'épopée médiévale. In: Mélanges de langue et de littérature du moyen âge et de la Renaissance offerts à Jean Frappier. 2 t. Genebra: Droz, 1970, t. 1, p. 483-497, p. 493-494. 
materialização é atestada em Saint-Denis em 1505, embora seja seguramente anterior, ${ }^{68}$ desempenha aí um papel central. ${ }^{69}$ Uma História de Carlos Magno e de Rolando, redigida em latim por volta de 1140-1150, notadamente a partir de textos provenientes de Saint-Denis, retomou a ideia de que Carlos Magno teria entregue seu reino à abadia. ${ }^{70}$ Outro eco literário do "jogo de xadrez de Carlos Magno" poderia ser encontrado em uma cena do Romance de Persival, ou Conto do Graal, redigido entre 1181 e 1191 por Chrétien de Troyes para o conde Filipe de Flandres, no qual o cavaleiro Gauvain usa um tabuleiro como escudo, deixando cair as peças de xadrez monumentais "que eram de marfim, dez vezes maiores que o comum e de um material mais duro" e que são, em seguida, lançadas sobre a cabeça dos agressores. ${ }^{71}$

\section{A sagração do rei de França em Reims}

Os temas da instituição eclesiástica e da realeza se desenvolvem também em um rico conjunto de imagens gravadas nos flancos de um cilindro de marfim que tem a parte superior mais alta em um dos lados, ou seja, a forma abstrata de um rei do xadrez, que, segundo autores do século XIX, seria proveniente da catedral de Reims e que é hoje conservado no Musée national du Moyen Age, em Paris [fig. $7-10$, págs. 251 e 252]. A decoração e a grande dimensão dessa peça $(8,8 \mathrm{~cm}$ de altura e $6,2 \mathrm{~cm}$ de diâmetro), ocada em sua base (o que faz dela um recipiente), e o fato de que ela foi esculpida com uma extrema fineza na extremidade mais ampla de uma presa de elefante, sugerem que ela nunca serviu para jogar. ${ }^{72}$ Ora,

${ }^{68}$ Ver GABORIT-CHOPIN, Danielle (dir.). Le trésor de Saint-Denis, op. cit., p. 142-143.

${ }^{69}$ A Chanson indica, no entanto, que Carlos Magno o teria oferecido a Saint-Seurin de Bordeaux: "Vint a Burdeles la citét de renun, / desur l'alter seint Sevrin le baron / met l'oliphan plein d'or e de manguns - / Li pelerin le veient ki la vunt". Chanson de Roland, v. 3684-3687, op. cit., p. I/257.

${ }^{70}$ Karollellus atque pseudo-Turpini Historia Karoli Magni et Rotholandi. SCHMIDT, Paul Gerhard (ed.). Stuttgart/Leipzig: Teubner, 1996; ver a comparação com o falso diploma de Carlos Magno por GROTEN, Manfred. Die Urkunde Karls des Großen für St.-Denis von 813 (D 286), eine Fälschung Abt Sugers?. Historisches Jahrbuch. München: Alber, 108, 1988, p. 1-36, p. 16-19.

71 "Lors versa les eschas a terre; / D'ivoire furent, dis tanz gros / Qu'autre eschas et de plus durs os". CHRÉTIEN DE TROYES. Perceval ou le conte du Graal. V. 5896-5898, ver também v. 60006003. POIRION, Daniel (ed.). In: Idem (dir.). Chrétien de Troyes. Euvres complètes. Paris: Gallimard, 1994, p. 683-911, p. 830; 833. Em Éric et Énide, v. 6705-6706, sem dúvida composto em 1170, Chrétien de Troyes atribui “deus faudestués / D'ivoire" ao rei Arthur. DEMBROWSKI, Peter F. (ed.). Ibidem, p. 1-169, p. 163.

${ }^{72}$ Agradeço a Isabelle Bardiès-Fronty por ter podido examinar o objeto. A cavidade, hoje vazia, foi talhada de forma a ser a maior possível e se fechava na base através de uma peça, sem dúvida em marfim, se inscrevendo em uma ranhura, sendo fixada por chaves que passam nos orifícios feitos na banda inferior. Ver, no museu, o dossiê da restauração por Juliette Lévy em março de 2004. Ver GOLDSCHMIDT, Adolph. Die Elfenbeinskulpturen aus der Zeit der Karolingischen 
essa ambivalência funcional, característica principal do objeto, é esclarecida pela própria peça. Sob um frontão que caracteriza uma fachada, a Virgem está tronando com o Cristo; figurados quase de perfil, eles estão voltados para sua direita, em direção aos três magos que apresentam suas oferendas ao Menino. À esquerda deles, um homem barbudo vestido à moda antiga segura um rolo. Para além dele, o rei Herodes é representado sentado, com a cabeça bem afundada entre os ombros e apoiada em sua mão esquerda; ele segura seu cetro obliquamente entre as pernas, paralelamente à lança do guarda a seu lado, enquanto faz ler a profecia que anuncia o nascimento de um rei de Israel em Belém, depois que os magos, alertados pela estrela, haviam-lhe perguntado o caminho. A cena seguinte é a do massacre dos inocentes, ordenado por Herodes, por temor a esse rei dos judeus recém-nascido. ${ }^{73}$ No lado oposto ao da Virgem com o Menino, o Cristo adulto é batizado no Jordão, e uma inscrição sobre uma faixa vertical à sua direita designa a pomba descendo na direção de sua fronte: spiritum ecce dei, "eis o espírito de Deus". Na parte posterior da peça, há três arcos acima do primeiro registro que é dedicado ao Cristo. Neles são figuradas cenas pertencendo, aparentemente, à lenda de São Pedro: à esquerda, um batismo, que seria o do centurião Cornélio, o primeiro não judeu admitido entre os cristãos; no centro, um bispo adormecido, guardado sob o arco da direita por dois homens, um dos quais é equipado de uma lança e de um escudo. Trata-se, provavelmente, de Pedro, aprisionado em Roma por Herodes e reconfortado pela aparição, acima dele, do anjo que o libertará e que lhe sussurra "não se deixe abater", de acordo com a inscrição sobre o arco central e sobre a faixa que separa os registros. ${ }^{74}$

Essas imagens confrontam os dois exemplos reais, dos magos e de Herodes, não apenas por suas atitudes de oferenda ou de perseguição ao Cristo menino, mas também por sua relação com a instituição eclesiástica. Esta é figurada por São Pedro, pela Virgem tronando, que pode evocar a Ecclesia, e sobretudo pela estrutura arquitetônica cujos diferentes elementos - frontão, tetos, arcadas, colu-

und Sächsischen Kaiser. VIII.-XI. Jahrhundert. 2 t. Berlim: Deutscher Verlag für Kunstwissenschaft, 1914-1918; 1969-1970, t. 2, n. 143, p. 43-44, pl. XL, que identifica o objeto como uma rainha do xadrez em razão da representação da Virgem; GABORIT-CHOPIN, Danielle. Ivoires du Moyen Âge. Fribourg: Office du Livre, 1978, n. 97, p. 99 e 197, que vê nela um relicário; KLUGE-PINSKER, Antje. Schach und Trictrac, op. cit., p. 30-32, que reconhece aí um rei ou uma rainha, sem explicar sua função. O objeto não aparece nos inventários da catedral de 1669, 1790 e 1792, editados por TARBÉ, Prosper. Trésors des églises de Reims. Reims: Assy, 1843. Não pude verificar os inventários da abadia de Saint-Rémi.

${ }^{73}$ Ver Mt. 2,1-18.

74 “Angelus eum blanda voce sic afatur: 'ne frangaris"'. Ver, para o batismo, At 10,1-48 e 12,3-19 para o aprisionamento. Herodes morre logo em seguida: At 12,20-25. 
nas - organiza as relações de sentido entre as figuras. O dom do primeiro mago, sublinhado pelo tamanho exagerado de suas mãos e das do Cristo, destaca-se sobre uma grande torre redonda integrada ao restante da arquitetura, enquanto, no lado oposto, uma torre angulosa, isolada, quebrada, erige-se à direita do massacre dos inocentes. As cabeças dos três magos, todas fazendo um mesmo gesto, são associadas por um mesmo arco e por um mesmo nível arquitetônico, enquanto uma máscara monstruosa emerge acima de Herodes a partir de um ângulo do edifício, ao lado do tumulto do massacre. Essas oposições são variadas com fineza: o rolo fechado do homem de pé sob o arco ornado de folhagens adjacente à fachada, a maior das figuras, e que parece ser um tipo de guardião do direito, entra em relação com aquele, desenrolado, do escriba que se curva na direção de Herodes, para ler a profecia.

No contexto de Reims, essas imagens reais e eclesiásticas não poderiam deixar de evocar a lembrança do batismo do rei Clóvis pelo bispo Remígio, por volta de 498, acontecimento fundador para a realeza franca. A cena do batismo na arcada superior, amplificada pela cena vizinha do batismo do Cristo, pode também ser relacionada ao batismo de Cornélio por Pedro e ao de Clóvis por Remígio que ecoaram, para os francos, o gesto de conversão inaugurado por Pedro para todas as nações não judias, ou seja, pagãs. ${ }^{75}$ A arquitetura, que evoca ao mesmo tempo a Igreja em geral e um edifício localizado, reforça essa flutuação entre a Igreja de Roma e o arcebispado de Reims. ${ }^{76} \mathrm{O}$ bispo adormecido reconfortado pelo anjo pode figurar Pedro, mas também um arcebispo de Reims que se beneficiaria da graça divina frente ao poder militar, evocado pelos soldados de Herodes, assim como pela própria forma do rei do xadrez. A peça arvora, portanto, uma escolha de imagens que a situam entre Roma e Reims, que são ligadas pela analogia, e entre a instituição eclesiástica e o poder real, envolvidos em uma interação segundo a qual o soberano pode agir negativamente, massacrando e aprisionando, tal qual Herodes, ou positivamente, deixando-se transformar pela conversão e pelo batismo. Diante das opções possíveis, o próprio objeto já toma partido, na qualidade de figura lúdica do rei profano transformado em relicário e em suporte de imagens. A bela qualidade das esculturas sugere que pode ter sido um dom do rei de França à igreja de Reims. Quer isso tenha de fato ocorrido ou não, o que

\footnotetext{
${ }^{75}$ Ver, sobre São Remígio, ISAÏA, Marie-Céline. Rémi de Reims. Mémoire d'un saint, histoire d'une Église, Paris: Cerf, 2010.

${ }^{76}$ Sobre a assimilação dos edifícios eclesiásticos à Igreja como instituição, ver IOGNA-PRAT, Dominique. La Maison Dieu. Une histoire monumentale de l'Église au Moyen Âge. Paris: Seuil, 2006, p. 119-152 e 521-537 sobre a figura do rei construtor de igrejas.
} 
importa é que o objeto pode ter sido, de fato, um presente. Isso indicaria, em todo caso, as circunstâncias e os desafios de uma sagração real, já que Reims estava regularmente implicada neste ritual. Poder-se-ia precisar esse contexto?

A peça foi datada por meio de comparações estilísticas que não possuem realmente caráter de evidência. Adolph Goldschmidt, que julga "difícil determinar o lugar de origem", sublinha o aspecto carolíngio do grupo dos magos e "crê constatar aproximações" com um grupo de marfins espetaculares atribuídos a um "mestre de Echternach", ativo por volta de 990, propondo como datação o século XI. Danielle Gaborit-Chopin precisa ser o terceiro quartel do século XI, colocando-o em relação com altares portáteis renanos - embora os dois objetos citados sejam de qualidade bem inferior. ${ }^{77}$ Essas propostas implicam a existência de dois soberanos candidatos: Henrique I e Filipe I, sagrados em Reims em 1027 e em 1059. As sagrações em Reims precedentes ocorreram em 922 e 954, e as que se seguiram aconteceram em 1129 e 1131 , e depois somente em $1179 .{ }^{78}$ Ora, a hipótese de que a peça tenha sido feita no contexto disputado das sagrações de 1129 e 1131 permite, sem dúvida, explicá-la melhor.

A coroação de Luís VI em Orléans em 1108 havia, de fato, colocado em causa o privilégio de Reims de sagrar os reis de França, dando origem a uma incerteza da qual Suger buscou se aproveitar nos anos de 1120, como vimos, antes que Reims retomasse a frente. O monumento da abadia de Saint-Rémi de Reims, já evocado, foi criado nesse contexto de concorrência, de argumentação e de competição, provavelmente nos anos de 1130. Ele apresentava, ao centro, uma figura tronando sob um frontão ornado de folhagens, segurando na mão um modelo de edifício eclesiástico, flanqueado, à sua direita, por três clérigos que se inclinam em sua direção com a mesma atitude dos reis magos e, à sua esquerda, por cinco outros personagens, dos quais o mais próximo a ela consulta um livro. Essas imagens só podem ser interpretadas com precaução, em razão das imperfeições prováveis

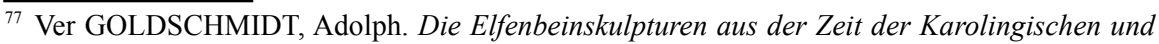
Sächsischen Kaiser, op. cit., t. 2, p. 43-44; GABORIT-CHOPIN, Danielle. Ivoires du Moyen Âge, op. cit., p. 197.

${ }^{78}$ Ver BAUTIER, Robert Henri. Sacres et couronnements sous les Carolingiens et les premiers Capétiens: recherches sur la genèse du sacre royal français. Annuaire-Bulletin de la Société de l'histoire de France. Paris: Société de l'histoire de France, 1987-1988 [1989], p. 7-56; reimpr. in: Idem. Recherches sur l'histoire de la France médiévale. Des Mérovingiens aux premiers Capétiens. Gower: Variorum, 1991, p. 7-56, p. 52-53; BUR, Michel. Aux origines de la "religion de Reims". Les sacres carolingiens: un réexamen du dossier (751-1131). In: ROUCHE, Michel (dir.). Clovis, histoire et mémoire. 2 t. Paris: Presses de l'Université de Paris-Sorbonne, 1997, t. 2. Le baptême de Clovis, son écho à travers l'histoire, p. 45-72. 
de sua descrição e da gravura a partir da qual a conhecemos,${ }^{79}$ mas a similitude com a figuração da Virgem na peça de xadrez é bastante forte.

O elemento mais marcante, visualmente, da peça de xadrez, e que primeiro chama a atenção, é a estrela que guia os reis magos até o Cristo, figurada justo acima do frontão e dominando-o por seu tamanho. Foi escavada, no marfim, uma área para abrigar uma folha de metal, provavelmente recoberta de ouro, como testemunham os traços de liga de cobre e um orifício de fixação. Ora, esse astro tem a forma atípica de uma gota, que brilhava, se considerarmos o antropomorfismo da peça de xadrez, sobre a fronte do rei. Ela designaria, provavelmente, o óleo com o qual o arcebispo de Reims ungia o rei no momento da sagração. A concorrência com Saint-Denis havia sido a oportunidade para reativar uma lenda carolíngia, segundo a qual uma ampola de óleo teria milagrosamente descido do céu, através de uma pomba, quando da sagração de Clóvis por Remígio: a sagração de 1131 é a primeira para a qual o uso desse óleo divino é atestado. $\mathrm{Na}$ peça de xadrez, a pomba que desce sobre o Cristo em seu batismo é representada de forma bastante distinta, talvez para reforçar essa alusão.

Uma última questão diz respeito ao apêndice vegetal que se erige atrás da peça, no limite da parte em relevo que determina sua forma de rei do xadrez. Seu desgaste mostra que ele serviu frequentemente de apoio para se manipular o objeto. Que a ornamentação ganhe em relevo nessa parte central é algo comum nas peças de xadrez, mas essa amplitude não é habitual e não teve ainda nenhuma interpretação satisfatória. Esse motivo de árvore, ou de florão, ou de flor-de-lis, poderia, eventualmente, evocar um elemento da coroa: associada a Maria desde o século XI, a flor-de-lis se tornou, justamente nesse período, notadamente sob a influência do abade Suger, um emblema da realeza capetíngia, que foi assim colocada sob o signo da Virgem, assim como, justamente, esta peça de xadrez. ${ }^{80}$

Nas igrejas de Münster e de Aix-la-Chapelle no Império, por volta do ano mil, e depois em Saint-Denis e em Reims no Reino de França, no início do século XII, as peças de xadrez serviram, pois, aos esforços de definição do poder soberano. Esses quatro empregos diferem um do outro tanto pelo uso das peças quanto pelas ideias que expressam, o que testemunha um grande domínio de potencialidade simbólica dessas imagens. A peça de cristal ocada de Münster

${ }^{79}$ Ver MARTÈNE, Edmond, DURAND, Ursin. Voyage littéraire de deux religieux bénédictins de la congrégation de Saint-Maur. 2 t., Paris: Delaulne et Montalant, 1717-1724, t. 2, p. 80-83; NEES, Lawrence. The Fastigium, op. cit.

${ }^{80}$ Ver BEDOS REZAK, Brigitte. Suger and the symbolism of royal power, op. cit., p. 100; PASTOUREAU, Michel. Une fleur pour le roi. Jalons pour une histoire médiévale de la fleur de lis. In: Idem. Une histoire symbolique, op. cit., p. 99-110. 
manifesta a presença e a sacralidade do imperador, apoiando-se em São Paulo e defendendo sua igreja. A série de peças do ambão de Aix-la-Chapelle, valendose também da faculdade de representação e de figuração das peças de xadrez, coloca visualmente em cena um sistema de relações complexas entre os atores militares do Império, o imperador Henrique II e o Cristo crucificado concebido como o rei dos reis. Um século mais tarde, Suger evoca, por sua vez, a ideia imperial através da figura de Carlos Magno, ao mesmo tempo em que utiliza o contrapoder constituído pelo papado para instaurar, também, uma relação ideal entre o reino de França e sua igreja, apresentando como antiguidades peças de marfim espetaculares, adquiridas na Itália do sul. A iniciativa passou para o lado eclesiástico, em um ato que mostra que os dons de peças de xadrez às igrejas tinham se tornado suficientemente familiares para que uma tal atribuição fosse significativa naquele contexto de rivalidades eclesiásticas. Por fim, o refinamento técnico e conceitual das imagens da peça de marfim de Reims, que só tem de peça de xadrez sua forma geral, parece constituir uma resposta à empresa de SaintDenis. Nesses quatro dons de peças de xadrez a igrejas, que se situam em duas extremidades cronológicas de uma série mais importante, a figura do imperador ou do rei parece se abstrair e se destacar das figuras subalternas, adquirindo uma sacralidade particular. O xadrez favorece, portanto, a junção do poder e das igrejas, o reforço de projetos imperiais ou reais, em atos de imaginação que precederam o desenvolvimento de formas estatais mais elaboradas.

Recebido: 20/05/2011 - Aprovado: 20/09/2011. 